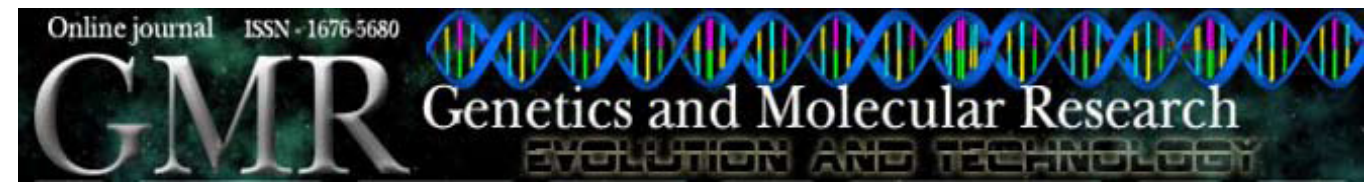

\title{
Genetic variability in wild genotypes of Passiflora cincinnata based on RAPD markers
}

\author{
C.B.M. Cerqueira-Silva ${ }^{1,2}$, L.D.H.C.S. Conceição ${ }^{3}$, E.S.L. Santos ${ }^{1,2}$, \\ C.B. Cardoso-Silva ${ }^{2}$, A.S. Pereira ${ }^{4}$, A.C. Oliveira ${ }^{5}$ and R.X. Corrêa ${ }^{4}$ \\ ${ }^{1}$ Departamento de Estudos Básicos e Instrumentais, \\ Universidade Estadual do Sudoeste da Bahia, Itapetinga, BA, Brasil \\ ${ }^{2}$ Instituto de Biologia, Universidade Estadual de Campinas, Campinas, SP, Brasil \\ ${ }^{3}$ Centro de Pesquisa Agropecuária dos Cerrados, \\ Empresa Brasileira de Pesquisa Agropecuária, Planaltina, DF, Brasil \\ ${ }^{4}$ Departamento de Ciências Biológicas, Universidade Estadual de Santa Cruz, \\ Ilhéus, BA, Brasil \\ ${ }^{5}$ Departamento de Ciências Naturais, Universidade Estadual do Sudoeste da Bahia, \\ Vitória da Conquista, BA, Brasil \\ Corresponding author: R.X. Corrêa \\ E-mail:ronanxc@uesb.br
}

Genet. Mol. Res. 9 (4): 2421-2428 (2010)

Received August 25, 2010

Accepted October 2, 2010

Published December 21, 2010

DOI 10.4238/vol9-4gmr981

\begin{abstract}
The genetic diversity and characteristics of commercial interest of Passiflora species make it useful to characterize wild germplasm, because of their potential use for fruit, ornamental and medicinal purposes. We evaluated genetic diversity, using RAPD markers, of 32 genotypes of Passiflora cincinnata collected from the wild in the region of Vitória da Conquista, Bahia, Brazil. Thirteen primers generated 95 polymorphic markers and only one monomorphic marker. The mean genetic distance between the genotypes estimated by the complement of the Dice index was 0.51 (ranging from 0.20-0.85), and genotype grouping based on the UPGMA algorithm showed wide variability among the genotypes. This type of information contributes
\end{abstract}


to identification and conservation of the biodiversity of this species and for the identification of pairs of divergent individuals for maximum exploitation of existing variability.

Key words: Genetic breeding; Genetic variability; Grouping analyses; Coefficient of similarity; Biodiversity conservation; Molecular marker

\section{INTRODUCTION}

The genus Passiflora L. consists of more than 400 species widely distributed in the tropics, mainly in Brazil, which is the birthplace of at least one third (Ganga et al., 2004). In general, wild species are used as sources of resistance to diseases or for the improvement of desirable characteristics. However, some species have high agronomic potential. Passiflora cincinnata Mast. is a native plant with reports of spontaneous occurrence in the northeast, southeast (Oliveira and Ruggiero, 2005) and midwest (Amorozo, 2002) regions of Brazil. This species is popularly known in Brazil as "maracujá mochila", "maracujá do-mato" or "maracujá tubarão". It is considered potentially important for use as rootstock, since it is tolerant to diseases and nematodes (Zucareli et al., 2007). In the region of Recôncavo, in the Brazilian State of Bahia, its fruits, which are used as food in the form of juice, are sold in street markets and grocery stores. The fruits of $P$. cincinnata Mast. are resistant to shipping and handling, and have greater durability compared to the yellow passion fruit (Oliveira and Ruggiero, 2005.) Total fruit mass is the most important aspect in total variability among morphological descriptors in accessions of P. cincinnata Mast. collected in northeastern Brazil (Araújo et al., 2008), thus highlighting the potential of this species for cultivation in order to produce juice. Other attributes related to $P$. cincinnata Mast. make this species suitable for ornamental or medicinal purposes.

Tropical flowers are a growing market in Brazil and worldwide (Pizano, 2005), while tropical fruits such as banana (Souza et al., 2008) and pineapple (Pasqual et al., 2008) have been used for this purpose. Eccentric flowers, lush foliage and continuous and plentiful bloom, make Passiflora suitable for the market of ornamental plants (Abreu et al., 2009). However, this potential is not exploited in Brazil. The potential use of species, such as $P$. alata and $P$. edulis Sims. in the southeast region, $P$. coccinea Aubl. in the north and $P$. cincinnata Mast. in the northeast, is limited to fences and arbors with the use of the fruits without the sole purpose for ornamentation (Peixoto, 2005).

Passion fruit was discovered as a medicinal plant in 1867, when passiflorine aroused great interest in medicine. Still, the therapeutic properties of passion fruit were already used by natives before the discovery of the Americas (Milward-de-Azevedo, 2008). The exploitation of genetic resources of medicinal plants in Brazil is largely related to the extensive collection and extraction of wild material (Rodrigues and Carvalho, 2001). Several ethnobotanical or ethnomedicinal surveys report the use of $P$. cincinnata Mast. in local communities in the midwest (Amorozo, 2002) and northeast (Silva et al., 2002; Dantas and Guimarães, 2007) regions of Brazil for therapeutic purposes. Agra et al. (2007) described the use of leaves of $P$. cincinnata Mast. in the form of tea, for the treatment of hemorrhoids and venereal diseases.

Thus, pre-breeding works aiming to evaluate and conserve the variability of this species in order to allow exploitation in a sustainable manner are essential. Molecular markers are currently a tool that can aid in estimating genetic diversity by determining the genetic relationships 
among materials, hence defining the crossbreeding or selection of parents and the introgression of genes during the improvement process (Pereira et al., 2009). An enormous amount of information on genomes has been generated, thus providing numerous opportunities for exploitation of genetic variability in both agronomic species and wild germplasm (Ferreira and Grattapaglia, 1998).

In the present study, we quantified, by means of random amplified polymorphic DNA (RAPD) primers and the complement of the Dice index, the dissimilarity of wild genotypes of Passiflora trintae Sacco originating from the region of Vitória da Conquista, Bahia State, Brazil, belonging to the active collection of Passiflora of the Universidade Estadual do Sudoeste da Bahia (UESB). The results are discussed in terms of characterization and conservation.

\section{MATERIAL AND METHODS}

We used 32 specimens of $P$. cincinnata Mast. collected in fragments of a liana forest in Vitória da Conquista, Bahia State, Brazil (14 $53^{\prime} \mathrm{S}$ and $40^{\circ} 47^{\prime} \mathrm{W}$, elevation of $900 \mathrm{~m}$; average annual precipitation of 700-800 mm, concentrated between November and March, average annual temperature of $20-22^{\circ} \mathrm{C}$ ) (Instituto Nacional de Meteorologia/Ministério da Agricultura e Abastecimento), and belonging to the Active Collection of Passiflora Work Germplasm of the UESB, Vitória da Conquista campus (CAGT-Passiflora/UESB 'Planalto de Conquista'). For DNA extraction, we adopted the method described by Doyle and Doyle (1990). For amplifying reactions, the patterns described for the RAPD technique were adopted (Williams et al., 1990). Also, 13 RAPD primers from Operon ${ }^{\circ}$ Technologies and the University of British Columbia were used (UBC). These primers were previously selected because they presented molecular polymorphism among the 47 primers tested, whose series were $\operatorname{OPD}(02,08,12,18), \operatorname{OPE}(03,04,05,06,07$, $11,12)$ and $\mathrm{UBC}(23$ and 25$)$.

The amplification products were separated by $1.6 \%$ agarose gel electrophoresis, stained with ethidium bromide, submerged in $1 \mathrm{X}$ TBE (composed of Tris-borate and EDTA buffer), and the results photographed with a Kodak transluminator (EDAS 290) under ultraviolet light. Molecular markers generated by different primers were analyzed for the presence or absence of bands. Only the bands with high sharpness and reproducibility were considered. To ensure reliability of data, the electrophoretic patterns were evaluated by two researchers. Moreover, only the consensus pattern was considered for analysis.

Multivariate statistical analysis was performed: $i$ ) estimate on the complement of genetic similarity $\left(\mathrm{dg}_{\mathrm{ij}}=1-\mathrm{sg}_{\mathrm{ij}}\right.$; similarity $=\mathrm{sg}_{\mathrm{ij}}$ and dissimilarity $\left.=\mathrm{dg}_{\mathrm{ij}}\right)$ based on the coefficient of Dice (1945); ii) grouping of genotypes by using the method of arithmetic averages (UPGMA), the latter being selected from other hierarchical methods (Ward, Gower, more distant neighbor, and nearest neighbor) for presenting the lowest distortion and stress values, as well as the highest values of cophenetic correlations for the species (Cerqueira-Silva et al., 2009); iii) the projection of data in the two-dimensional space, and $i v$ ) assessing the quality of clusterings and the projection into the two-dimensional space by estimating distortion values, stress and correlation.

To assess the efficiency of grouping matrices and the projection of data into the twodimensional plane, the classification proposed by Kruskal (1964) was used for stress levels, as follows: perfect ( $\leq 5 \%)$, excellent $(>5 \%$ and $\leq 10 \%)$, good $(>10 \%$ and $\leq 20 \%)$, regular $(>20 \%$ and $\leq 40 \%$ ), and poor $(>40 \%)$. Statistical analyses were performed using the Genes, Windows version software (Cruz, 2006). 


\section{RESULTS AND DISCUSSION}

Among the 13 primers used, a total of 96 markers were amplified. An average of 7.4 marks per primer was generated while only one was found to be monomorphic at the OPE03 primer. The number of different polymorphic traits ranged from 2 (OPE-12) to 19 (OPD02) (Table 1). Characterization studies in P. cincinnata Mast. involving molecular markers are incipient. A reduced number of accessions are often used along with other species of the genus Passiflora L. (Aukar et al., 2002; Viana et al., 2003). Yet, the high degree of polymorphism detected is consistent with the observed variability based on morphoagronomic descriptors (Araújo et al., 2008). These results can be attributed to and are consistent with the reproductive system of this species. $P$. cincinnata Mast. is allogamous, with a natural fructification mean of 50\%, and it has self-incompatible flowers (Oliveira and Ruggiero, 2005).

\begin{tabular}{|c|c|c|c|c|}
\hline Primers & Sequence $5^{\prime} 3^{\prime}$ & Polymorphic bands & Monomorphic bands & Bands for primer \\
\hline OPD-02 & GGACCCAACC & 19 & 0 & 19 \\
\hline OPD- 08 & GTGTGCCCCA & 7 & 0 & 7 \\
\hline OPD-12 & CACCGTATCC & 10 & 0 & 10 \\
\hline OPD-18 & GAGAGCCAAC & 7 & 0 & 7 \\
\hline OPE-03 & CCAGATGCAC & 3 & 1 & 4 \\
\hline OPE-04 & GTGACATGCC & 6 & 0 & 6 \\
\hline OPE-05 & TCAGGGAGGT & 5 & 0 & 5 \\
\hline OPE-06 & AAGACCCCTC & 4 & 0 & 4 \\
\hline OPE-07 & AGATGCAGCC & 7 & 0 & 7 \\
\hline OPE-11 & GAGTCTCAGG & 6 & 0 & 6 \\
\hline OPE-12 & TTATCGCCCC & 2 & 0 & 2 \\
\hline UBC-23 & GTCCACACGG & 10 & 0 & 10 \\
\hline UBC-25 & ACCCCCGCCG & 8 & 0 & 8 \\
\hline Total & & 95 & 1 & 96 \\
\hline
\end{tabular}

The values found for the cophenetic correlation coefficient (0.76) and stress (14.3) are classified as "good" as per Kruskal (1964), suggesting a fit between the matrix of genetic dissimilarity and the graphical representation in the dendrogram, when compared with values obtained for two-dimensional projection (Table 2, Figure 1). The average distance revealed in the dissimilarity matrix generated from the molecular markers was 0.51 . Among the comparisons made, maximum and minimum distances of 0.85 and 0.20 were found, respectively (Table 3 ). These values corroborate with the variability found in other native fruits such as the pitanga tree, from 0.26 to 0.75 (Nogueira et al., 2007) and cabbage palm fruit, from 0.06 to 0.67 (Oliveira et al., 2007).

Table 2. Efficiency of clustering matrices and the projection of distances in two-dimensional plane, based on the diversity observed among Passiflora cincinnata Mast. genotypes by accessing the polymorphism obtained by means of RAPD.

\begin{tabular}{lcr}
\hline Criterions & \multicolumn{2}{c}{ Methods of viewing } \\
\cline { 2 - 3 } & Grouping of genotypes & Projection of the distances \\
\hline Distortion & 2.05 & 55.6 \\
Correlation* & 0.76 & 0.49 \\
Stress & 14.3 & 61.1 \\
\hline
\end{tabular}

*The coefficient of cophenetic correlation was used for the clustering of genotypes, while the correlation between original distance and that projected for the two-dimensional plane was used for the projection of distances. 


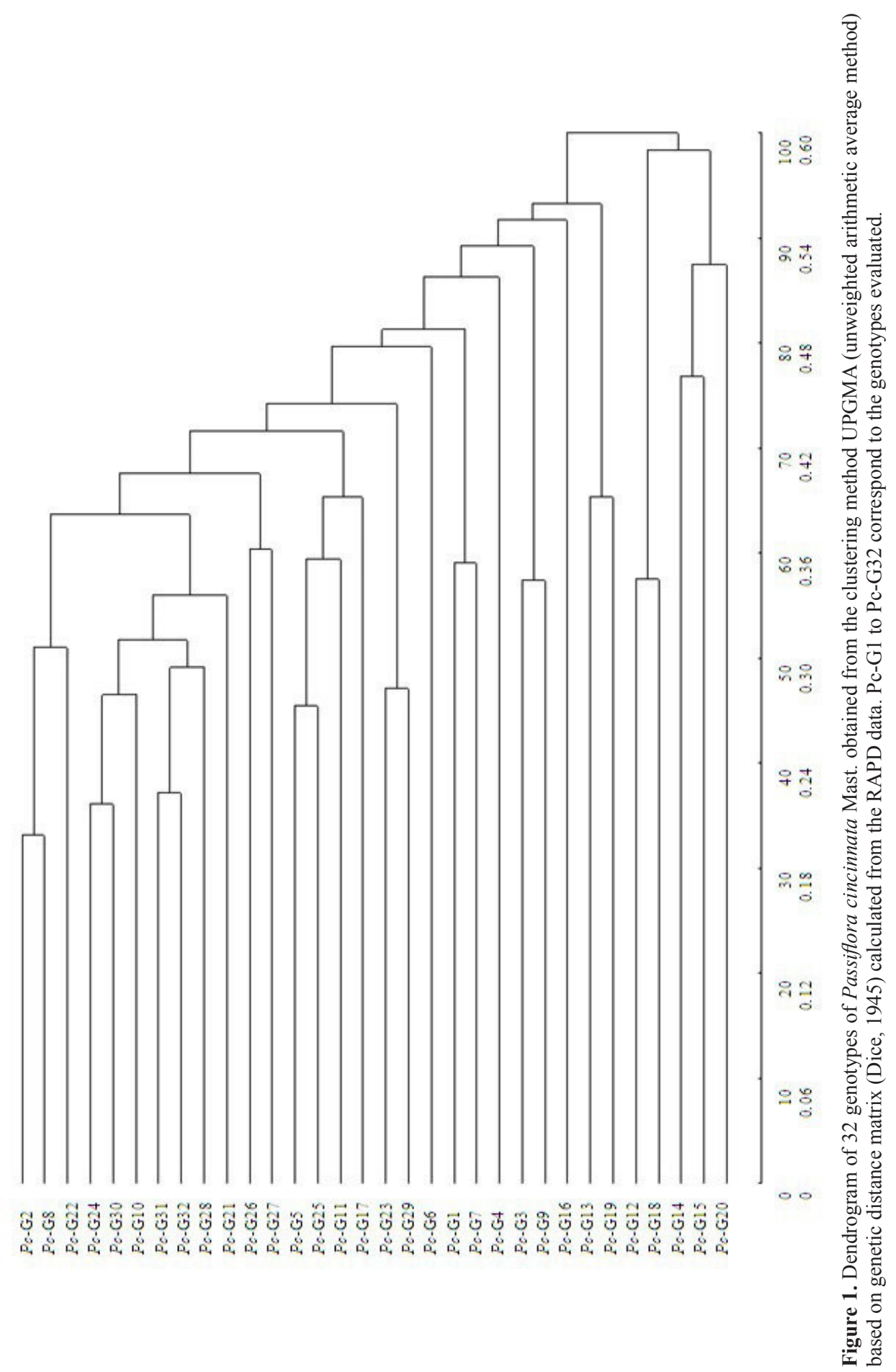




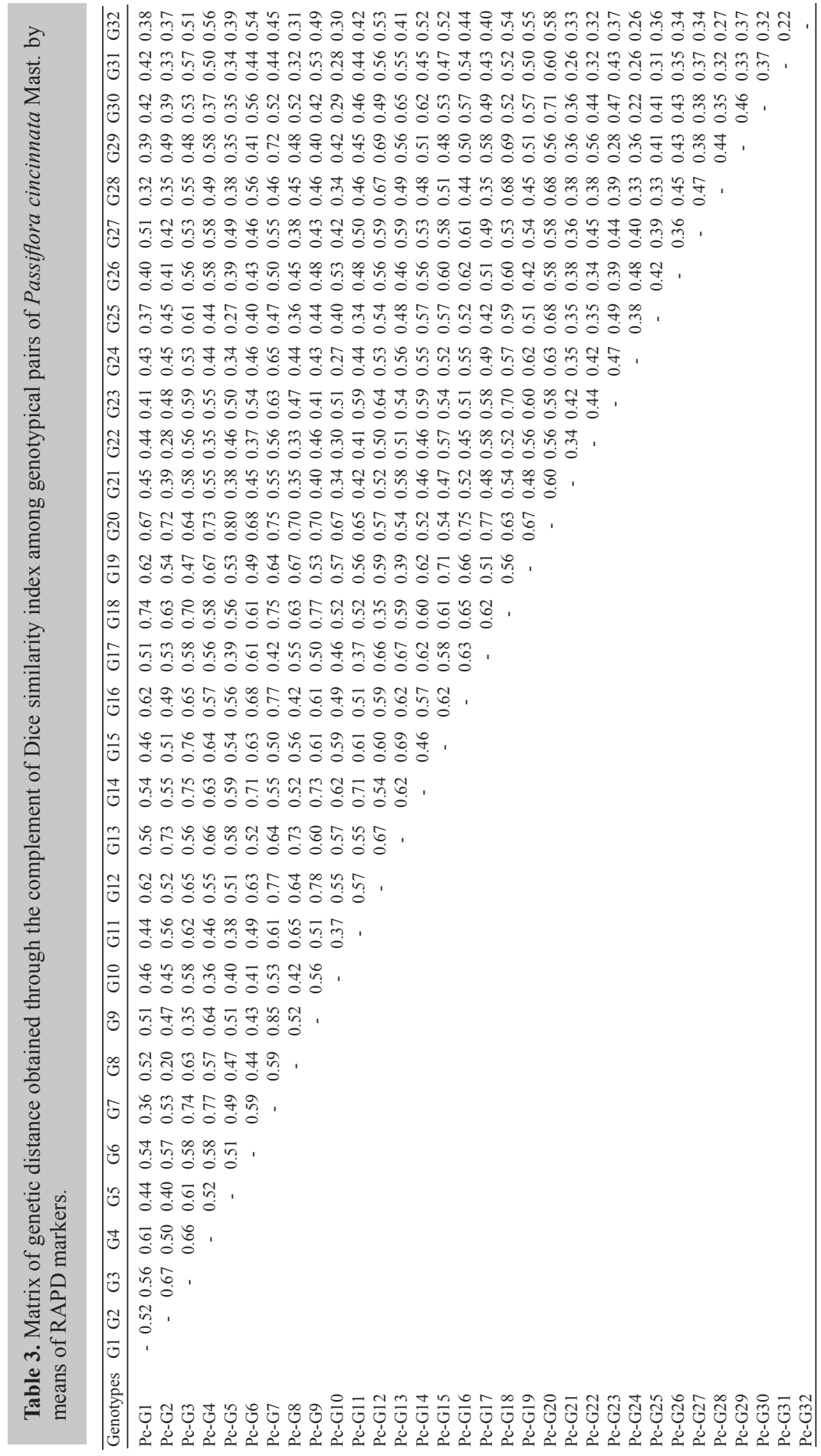


In other species of the genus Passiflora L. there is less variability characterizations based on RAPD markers. Variations between 0.03 to 0.42 were observed for P. nitida Kunth. (Junqueira et al., 2007), 0.09 to 0.50 for P. edulis Sims. (Bellon et al., 2007), 0.09 to 0.32 for $P$. alata (Bellon et al., 2009), 0.07 to 0.42 for $P$. trintae (Cerqueira-Silva et al., 2010a), and 0.12 to 0.19 for $P$. edulis Sims (Cerqueira-Silva et al., 2010b); values closer to those found in acerola $(0.13$ to 0.35$)$, which is an introduced fruit species with a narrow genetic base (Salla et al., 2002). It is noteworthy that the collections studied in these species have to do with accessions of different regions of Brazil. However, except for P. nitida and P. trintae, cultivated populations were also used. These studies of divergence reinforce the importance of the conservation of native wild species for the sustainable exploitation of genetic resources and existing variability. The lowest variability found in other passiflora species, as compared to values obtained for $P$. cincinnata Mast., indicates a possible genetic erosion.

The genetic diversity-based markers can help the breeder determine crosses and selection of parents (Ferreira and Grattapaglia, 1998; Pereira et al., 2009). Jung et al. (2008) found that heritability estimates and genetic gain in fruit characters of $P$. alata are dependent on crossing. Authors suggest that this occurs because the progenitors present distinct genes controlling these characters ("genetic background" divergence). Crossings among genetically distant materials, such as $P c-\mathrm{G} 5 v_{s} P c-\mathrm{G} 7$ and $P c-\mathrm{G} 20 v_{s} P c$-G9 (Table 3), and with superior performance, are likely to promote the formation of populations that recover superior recombinants, whereas the need for a morphoagronomic characterization of similar genotypes was observed. Therefore, we must examine how this species should be exploited, either as an ornamental or medicinal plant, or for juice production, thus defining and testing which characters to evaluate for the chosen purpose. Thus, the most divergent genotypes within the population studied can be used for improvement, once the need to characterize them agronomically is established, according to the objectives of the program type (ornamental, medicinal or fruits).

\section{ACKNOWLEDGMENTS}

Juliane dos Santos Amorim and the biologist Camile Barbosa Moreira contributed during the laboratory phases of the study. Research supported by CNPq and Programa de PósGraduação em Genética e Biologia Molecular of UESC, and is part of the Master's dissertation of C.B.M. Cerqueira-Silva.

\section{REFERENCES}

Abreu PP, Souza MM, Santos EA, Pires MV, et al. (2009). Passion flower hybrids and their use in the ornamental plant market: perspectives for sustainable development with emphasis on Brazil. Euphytica 166: 307-315.

Agra MF, Freitas PF and Barbosa-Filho JM (2007). Synopsis of the plants known as medicinal and poisonous in Northeast of Brazil. Rev. Bras. Farmacogn. 17: 114-140.

Amorozo MCM (2002). Use and diversity of medicinal plants in Santo Antonio do Leverger, MT, Brazil. Acta Bot. Bras. 16: $189-203$

Araújo FP, Silva N and Queiroz MA (2008). Genetic divergence among Passiflora cincinnata mast accessions based on morphoagronomic descriptors. Rev. Bras. Frutic. 30: 723-730.

Aukar APA, Lemos EGM and Oliveira JC (2002). Genetic variations among passion fruit species using RAPD markers. Rev. Bras. Frutic. 24: 738-740.

Bellon G, Faleiro FG, Junqueira KP, Junqueira NTV, et al. (2007). Genetic variability of wild and commercial passion fruit (Passiflora edulis Sims.) accessions using RAPD markers. Rev. Bras. Frutic. 29: 124-127.

Bellon G, Faleiro FG, Peixoto JR, Junqueira KP, et al. (2009). Genetic diversity obtained from cultivated population and 
native accesses of sweet passion fruit based on RAPD markers. Rev. Bras. Frutic. 31: 197-202.

Cerqueira-Silva CB, Cardoso-Silva CB, Conceicao LD, Nonato JV, et al. (2009). Comparison of coefficients and distance measurements in passion fruit plants based on molecular markers and physicochemical descriptors. Genet. Mol. Res. 8: 870-879.

Cerqueira-Silva CBM, Cardoso-Silva CB, Santos ESL, Conceição LDHCS, et al. (2010a). Genetic diversity in wild species of passion fruit (Passiflora trintae Sacco) revealed with molecular markers. Genet. Mol. Res. 9: 2123-2130.

Cerqueira-Silva CBM, Conceição LDHCS, Cardoso-Silva CB, Pereira AS, et al. (2010b). Genetic diversity in yellow passion fruit (Passiflora edulis Sims) based on RAPD. Crop Breed. Appl. Biotechnol. 10: 154-159.

Cruz CD (2006). Programa Genes: Biometria. Editora da Universidade Federal de Viçosa, Viçosa.

Dantas IC and Guimarães FR (2007). Plantas medicinais comercializadas no município de Campina Grande, PB. Rev. Biol. Farm. 1: 1-13.

Dice LR (1945). Measures of the amount of ecologic association between species. Ecology 26: 297-302.

Doyle JJ and Doyle JL (1990). Isolation of plant DNA from fresh tissue. Focus 1: 13-15.

Ferreira ME and Grattapaglia D (1998). Introdução ao Uso de Marcadores Moleculares em Análise Genética. 3rd edn. EMBRAPA-CENARGEN, Brasília.

Ganga RMD, Ruggiero C, Lemos EGM, Grili GVG, et al. (2004). Genetic diversity in yellow passion fruit utilizing fAFLP molecular markers. Rev. Bras. Frutic. 26: 494-498.

Jung MS, Vieira EA, Brancker A and Nodari RO (2008). Heritability and genetic gain in fruit of sweet passion fruit characteres. Rev. Bras. Frutic. 30: 209-214.

Junqueira KP, Faleiro FG, Ramos JD, Bellon G, et al. (2007). Genetic variability of wild passion fruit determined by molecular markers. Rev. Bras. Frutic. 29: 571-575.

Kruskal JB (1964). Multidimensional scaling by optimizing goodness of fit to a nonmetric hypothesis. Psychometrika 29: 1-27.

Milward-de-Azevedo MA (2008). Analysis of the valuation of the environment impact and the demand of phytotherapics coming from passion fruit in Brazil. Rev. FAE 11: 19-32.

Nogueira LR, Buttow MV, Castro CM, Costa RR, et al. (2007). Avaliação da Diversidade Genética entre Seleções de Eugenia uniflora L. Através de Marcadores AFLP. In: XVI Congresso de Iniciação Científica, Pesquisa e Responsabilidade Ambiental, IX Encontro de Pós Graduação, 27-29 de Novembro UFPel (Universidade Federal de Pelotas), Pelotas.

Oliveira JC and Ruggiero C (2005). Espécies de Maracujá com Potencial Agronômico. In: Maracujá: Germoplasma e Melhoramento Genético (Faleiro FG, Junqueira NTV and Braga MF, eds.). EMBRAPA Cerrados, Planaltina, 456-464.

Oliveira MSP, Amorim EP, Santos JB and Ferreira DF (2007). Genetic diversity among accessions of assai palm based on RAPD markers. Cienc. Agrotec. 31: 1645-1653.

Pasqual M, Santos FC, Figueiredo MA, Junqueira KP, et al. (2008). Protocol for in vitro micropropagation of ornamental pineapple. Hortic. Bras. 26: 45-49.

Peixoto M (2005). Problemas e Perspectivas do Maracujá Ornamental. In: Maracujá: Germoplasma e Melhoramento Genético (Faleiro FG, Junqueira NTV and Braga MF, eds.). EMBRAPA Cerrados, Planaltina, 456-464.

Pereira MG, Pereira TNS and Costa F (2009). Marcadores Moleculares no Pré-melhoramento. In: Marcadores Moleculares (Borém A and Caixeta ET, eds.). 2nd edn. Universidade Federal de Viçosa, Viçosa, 103-128.

Pizano M (2005). International market trends - tropical flowers. Acta Hortic. 683: 86.

Rodrigues VEG and Carvalho DA (2001). Etnobotanical survey of medicinal plants in the dominion of meadows in the region of the Alto do Rio Grande - Minas Gerais. Cienc. Agrotecnol. 25: 102-123.

Salla MFS, Ruas CF, Ruas PM and Carpentieri-Pípolo V (2002). The use of molecular markers in the genetic variability analysis of acerola (Malphighia emarginata). Rev. Bras. Frutic. 24: 15-22.

Silva KN, Agra MF and Baracho GS (2002). Estudo etnomedicinal e farmacobotânico comparativo entre Passiflora foetida L. e Passiflora cincinnata Mast. (Passifloraceae). Rev. Bras. Farm. 83: 51-55.

Souza EH, Costa MAPC, Santos-Serejo JA, Souza FDV, et al. (2008). Avaliação de Híbridos de Bananeira Ornamental no Segundo Ciclo de Produção. In: XX Congresso Brasileiro de Fruticultura, 54th Annual Meeting of the Interamerican Society for Tropical Horticulture, 12-17 de Outubro. Frutas para Todos: Estratégias, Tecnologias e Visão Sustentável: Anais INCAPER: Sociedade Brasileira de Fruticultura, Vitória.

Viana AP, Pereira TNS, Pereira MG, Souza MM, et al. (2003). Genetic diversity among yellow passion fruit commercial genotypes and among passiflora species using RAPD. Rev. Bras. Frutic. 25: 489-493.

Williams JG, Kubelik AR, Livak KJ, Rafalski JA, et al. (1990). DNA polymorphisms amplified by arbitrary primers are useful as genetic markers. Nucleic Acids Res. 18: 6531-6535.

Zucareli V, Ferreira G, Ferrari TB and Amaro ACE (2007). Desenvolvimento de mudas de Passiflora cincinnata Mast. com uso de reguladores vegetais. Rev. Bras. Biocienc. 5 (Suppl 2): 846-848. 